\title{
Frydman-Cohen-Karmon syndrome: a rare syndromic association of blepharophimosis
}

\author{
Rachna Meel, Nikitha Ayyadurai, Sahil Agrawal 지 , Deepsekhar Das
}

Dr Rajendra Prasad Centre for Ophthalmic Sciences, All India Institute of Medical Sciences, New Delhi, Delhi, India

\section{Correspondence to} Dr Deepsekhar Das; doc.deep.das@gmail.com

Accepted 6 June 2020

\section{DESCRIPTION}

Blepharophimosis refers to the reduced horizontal length of the palpebral aperture. It is found to be associated with multiple syndromes. ${ }^{1}$ FrydmanCohen-Karmon syndrome (FCKS) is an autosomal recessively inherited syndrome characterised by the presence of features, including blepharophimosis, blepharoptosis, prognathism, camptodactyly and syndactyly. ${ }^{2}$ Its inheritance pattern being autosomal recessive marks it as a separate entity from blepharophimosis ptosis epicanthus inversus syndrome (BPES), which usually follows an autosomal dominant pattern of inheritance but can also occur from spontaneous mutation. It is an extremely rare syndrome with unknown incidence with no specific molecular genetic data background.

A 13-year-old girl was presented to our outpatient department with drooping of both of her eyelids since birth (figure 1A,B). She was the first born in a family of healthy non-consanguineous married couple with three siblings, none of the others being affected. However, her parents gave the history of her great grandmother having similar facial features. She had a full-term birth with a birth weight of $2.7 \mathrm{~kg}$. There was no history of any developmental delay. Parents gave a history of her having webbed fingers in both of her hands and feet for which she had undergone surgery when she was 6 years old. She had

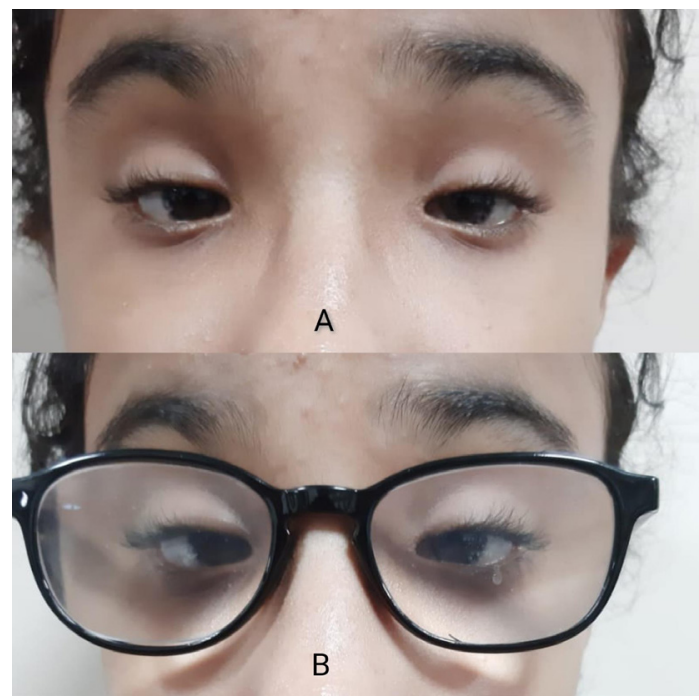

Figure 1 (A) Clinical picture of the patient showing bilateral ptosis, absent lid crease, frontalis overaction and blepharophimosis. (B) Clinical picture of the patient wearing glasses showing arched eyebrows indicating frontalis overaction to compensate for ptosis.

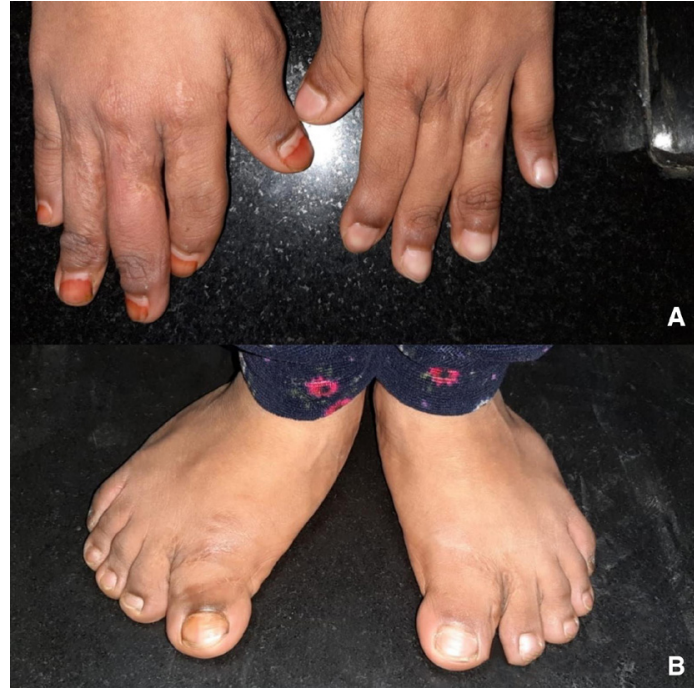

Figure 2 Clinical picture showing surgically corrected syndactyly of (A) hands and (B) legs.

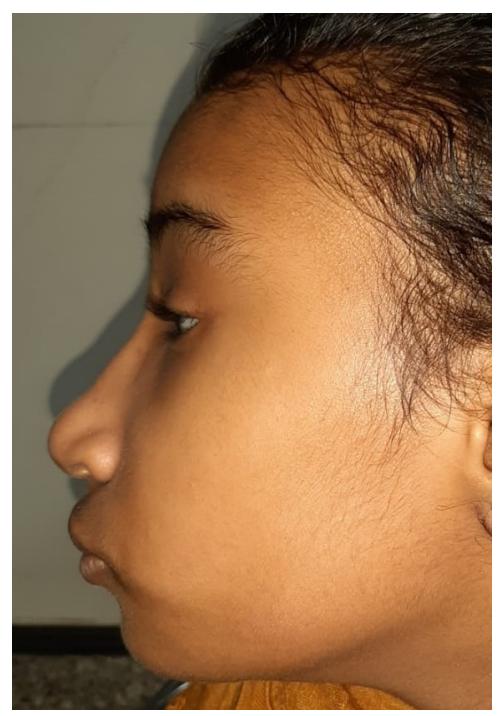

Figure 3 Clinical picture of the patient showing flat nasal bridge, malar hypoplasia and mandibular prognathism.

recurrent episodes of diarrhoea and was evaluated for the same and was diagnosed to have coeliac disease, with antiendomysial antibody positive. On general examination, it was found that she was $134 \mathrm{~cm}$ tall, which was grossly short for her age, being below $3 \mathrm{rd}$ percentile for her respective age group. She had broad hands and feet, short bent camptodactyly fingers. There were scars 


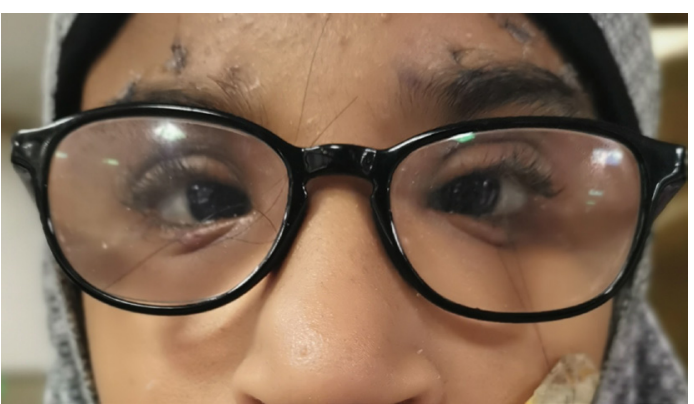

Figure 4 Postoperative clinical picture of the patient wearing glasses showing no frontalis overaction and formation of new lid crease indicating successful surgical outcome.

from previous surgery in second and third web spaces of both the hands (figure 2A). Similar scars were also noted in the first web space of both feet (figure 2B).

On systemic examination, no systemic disease was noted. On examining her face, she was noted to have a broad nasal bridge, with a prominent large nose, bilateral maxillary hypoplasia, mandibular prognanthism and thick lower lid vermilion (figure 3). On examination of her eyes she was seen to have bilateral blepharophimosis with horizontal palpebral fissure length of $23 \mathrm{~mm}$, blepharoptosis with margin reflex distance 1 of $-2 \mathrm{~mm}$, bilateral levator palpebralis superioris excursion of $2 \mathrm{~mm}$ along with telecanthus, inner canthal distance of $42 \mathrm{~mm}$, inter pupillary distance of $60 \mathrm{~mm}$ and outer canthal distance $88 \mathrm{~mm}$. Extraocular movements were normal and indirect ophthalmoscopy showed a healthy disc and macula with no peripheral treatable lesion. There was also evident lid lag, Bell's phenomenon in both eyes being fair. Her unaided vision was 4/60 and her best corrected visual acuity (BCVA) was 6/12 in both eyes and her cycloplegic refraction was $+5.00 \mathrm{DS} /+0.50 \mathrm{DC}$ at 90 and $+5.00 \mathrm{DS} /+0.50 \mathrm{DC}$ at 90 in the right and left eye, respectively.

A two-dimensional echocardiogram was done to rule out cardiac anomalies. Echocardiogram was obtained which also revealed no abnormalities. A genetic analysis was done to

\section{Patient's perspective}

My daughter was not looking well from her time of birth. We knew that she has many problems. I hope everything can be treated.

\section{Learning points}

Blepharophimosis can be associated with rare syndrome like Frydman-Cohen-Karmon syndrome, other than the more widely described blepharophimosis ptosis epicanthus inversus syndrome.

- Since there are no known genetic associations to date, a thorough paediatric examination is critical in making a diagnosis.

- A careful ophthalmological examination and proper visual assessment are essential to detect strabismus, refractive error, amblyopia and ptosis, thus, ensuring a proper visual development.

- Ptosis correction surgery can be performed either alone or as a staged procedure after medial canthoplasty. exclude BPES and no mutation was found in the FOXL2 gene or any other gene.

She was diagnosed to be a case of FCKS with both eye hypermetropia, blepharoptosis and blepharophimosis with telecanthus with coeliac disease. She started on a gluten-free diet and was prescribed spectacle correction for hypermetropia. A frontalis sling surgery was planned for the correction of her ptosis keeping in mind that her hyperopic glasses which by magnification will reduce the amount of apparent blepharophimosis. Her postoperative outcome was satisfactory (figure 4).

FCKS is an extremely rare inherited syndrome, which was first documented by Frydman et al in Egypt. ${ }^{2}$ They had reported it in six individuals in three related families of Yemenite with Jewish background with features of prognathism, synophyrs and thick eyebrows, along with additional features of short stature, borderline head circumference and toe syndactyly. The disease Online Mendelian Inheritance in Man entry number is 210745. There is no known genetic defect for this condition and at present the diagnosis is made based on a phenotype pattern. It differs from the typical BPES described by Kohn and Romano, ${ }^{3}$ with its inheritance pattern being autosomal recessive. Our case was a 13-year-old girl with a history of small palpebral apertures along with a history of syndactyly surgically repaired at a younger age. On examination, the patient had features similar to that described by Frydman et al, that is, female sex, short stature, history of syndactyly, camptodactly, mandibular prognathism, facial features being blepharophimosis and ptosis with telecanthus. However, our patient did not have a V-pattern esotropia. There was also a history of her great grandmother having similar facial features, which indicates an autosomal recessive condition. In 2002, there has been a report of two brothers having congenital ptosis with esotropia with a pedigree similar to that reported by Frydman et al; however, unlike FCKS both had undescended testis and one had polythelia. ${ }^{4}$ To our knowledge, this is the first reported case of FCKS in Asia.

The management of autosomal dominant BPES involves a two-staged procedure. The first stage involving correction of the horizontal shortening, followed by the correction of ptosis. ${ }^{5}$ In our case, the child being a hypermetropic, wearing high power hypermetropia glasses had a magnifying effect, thereby the patient did not require the correction of horizontal palpebral shortening.

Contributors RM, SA and DD participated in the clinical diagnosis of the patient and management of the patient. NA and DD prepared the manuscript.

Funding The authors have not declared a specific grant for this research from any funding agency in the public, commercial or not-for-profit sectors.

Competing interests None declared.

Patient consent for publication Parental/guardian consent obtained.

Provenance and peer review Not commissioned; externally peer reviewed.

\section{ORCID iDs}

Sahil Agrawal http://orcid.org/0000-0001-6667-249X

Deepsekhar Das http://orcid.org/0000-0002-4446-0274

\section{REFERENCES}

1 Tyers AG. The blepharophimosis-ptosis-epicanthus inversus syndrome (BPES). Orbit 2011;30:199-201.

2 Frydman M, Cohen HA, Karmon G, et al. Autosomal recessive blepharophimosis, ptosis, V-esotropia, syndactyly and short stature. Clin Genet 1992;41:57-61.

3 Kohn R, Romano PE. Blepharoptosis, blepharophimosis, epicanthus inversus, and telecanthus--a syndrome with no name. Am J Ophthalmol 1971;72:625-32.

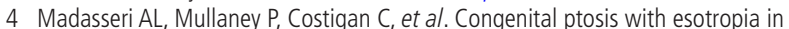
brothers. Clin Dysmorphol 2003;12:115-7.

5 Allen CE, Rubin PAD. Blepharophimosis-Ptosis-Epicanthus inversus syndrome (BPES). Int Ophthalmol Clin 2008;48:15-23. 
Copyright 2020 BMJ Publishing Group. All rights reserved. For permission to reuse any of this content visit https://www.bmj.com/company/products-services/rights-and-licensing/permissions/

BMJ Case Report Fellows may re-use this article for personal use and teaching without any further permission.

Become a Fellow of BMJ Case Reports today and you can:

- Submit as many cases as you like

- Enjoy fast sympathetic peer review and rapid publication of accepted articles

- Access all the published articles

Re-use any of the published material for personal use and teaching without further permission

Customer Service

If you have any further queries about your subscription, please contact our customer services team on +44 (0) 2071111105 or via email at support@bmj.com.

Visit casereports.bmj.com for more articles like this and to become a Fellow 